\title{
Irredentism and New Research Questions
}

\author{
Tanya Basok
}

In eastern Europe and central Eurasia country boundaries are being redrawn once again. Old empires are breaking up into smaller components. And in these newly created states, as well as in some old ones in this region, a general trend has been towards creating ethnic homogeneity to replace the ethnic mosaic that existed there for centuries. Consequently, members of ethnic minorities have felt compelled to return to the lands of their ancestors. Thus hundreds of thousands of ethnic Russians, dispersed throughout the former Soviet empire, have returned or are thinking of returning to Russia. Similarly, Pontic Greeks, Transylvanian Hungarians, Bulgarians from Russia, and Germans from Russia, Poland and Romania have been returning to their titular states.

Free emigration has always been considered unacceptable by Soviet authorities. However, family reunification and repatriation have been allowed for some groups. Thus Jews, Germans and Greeks, as well as a small number of Armenians, were able toleave. Although Soviet emigration policies have become more open recently, there is still an underlying assumption that only ablood tie or a community link warrants an exit visa. More relaxed emigration regulations put in place since 1987 have allowed Poles, Bulgarians, and Evangelical and Pentecostal Christians to join the emigration movement. (Heitman, this issue). Other ethnic minorities, such as Transylvanian Hungarians, have also felt the need to return to their historic homelands. As a distinct form of international migration, massive repatriation of ethnic minorities to their ancestral lands poses new questions for

Tanya Basok is a professor of Sociology and Anthropology at the University of Windsor, Ontario. researchers of international migration. An analysis of the Israeli situation, where this type of movementstarted in the early 1970 s and reached an unprecedented scale in the late 1980s, provides a useful comparison. Yet in many respects Israel's circumstances are unique. So as not to confuse this type of repatriation with the return of refugees to the country from which they have fled, I prefer using the term "irredentism," borrowing it from Anthony Smith (1983). ${ }^{1}$ This type of migration raises new questions in at least three areas.

First, when irredentism occurs, the analysis of a receiving country's immigration policy needs to include the im-

linked to national defence in the neverending Arab-Israeli conflicts. Similarly, the Greek government was happy to receive Greeks from Russia in order to stem the "shrinking of Hellenism" caused by the declining birth rates in Greece and the assimilation of Greeks abroad (Heitman, this issue). Thus the Greek Ministry of Foreign Affairs formed a coordinating service to propose a comprehensive plan for the reception of Soviet Greeks, including setting up hospitality centres, reception villages and housing projects (Kokkinos 1991). However, in other countries, due to the weight of economic pressures, conationals have not been so well received. In Hungary the initial wave of Transylvanian Hungarians produced profound sympathy among their conationals in Hungary, who offered these refu-

portance of nationalist sentiments, attachments and their relative role vis-àvis other factors. On an emotional level, it is difficult for the governments of receiving countries to turn down people with whom they share ancestry. But on a practical level, new arrivals may exacerbate existing problems in these countries: new postcommunist governments are plagued with sky-high inflation, shortages of goods and unemployment; Germany is facing economic problems caused by reunification with East Germany, making the arrival of ethnic Germans from Russia and eastern Europe undesirable (Salitan 1992, 102), and Israel is experiencing tremendous hardships in finding jobs and housing for masses of Soviet olim. Those countries, with nationalist priorities welcome ethnic "brothers and sisters" despite any economic hardships they may inflict on the receiving country. A clear example is Israel, where increased Jewish presence in the region is welcomed because it is gees warm reception and generous aid at the governmental and nongovernmental level. However, housing shortages, high inflation, unemployment and strained social services have put a stop to this policy of open reception (Noelte 1992). Similarly in Bulgaria, even though nationalist groups consider Bulgarian refugees arriving from Moldova and Tadjikistan to be of strategic importance in the areas where Turkish populations are concentrated, the new government perceives these migrants as a burden, given its political and economic problems (Iordanova, this issue). In Russia there is no official policy to deal with refugees to date (Orlova, this issue; Ryvkina and Turovskiy 1993). But certain measures, such as domicile registration, are taken to regulate the movement of refugees within Russia by channelling them to underpopulated and underdeveloped areas where their chances of subsistence are very dim (Basok and Benifand, this issue). At the same time,

Refuge, Vol. 13, No. 2 (May 1993) 
nationalist groups have formed committees to provide support for their conationals who are forced to return to Russia by discriminatory policies in the former Soviet republics.

Some governments, hoping to slow down the irredentist process, prefer assisting their conationals to rebuild their communities in the countries where they reside. In 1990 and 1991, the German government received over 500,000 ethnic Germans, two-thirds of whom were from the former Soviet Union (World Refugee Survey 1992), and at the present time the German consulate in Moscow is receiving almost 20,000 applications der Stalin. The Georgian government argues that Meskhetians should not be allowed to return because there is no land for them, the economy is too weak to support them, and the migrants have lost their Georgian culture and identity (Jones, this issue).

Irredentism as a form of international migration raises a second issue- the impact of conationals' irredentism on ethnic minorities in the receiving countries. Settlement of Soviet olim on the occupied territories was met with hostility by Israel's Palestinian population. The arrival of ethnic Bulgarians has put Bulgaria's Turkish population on guard

\section{Irredentism as a form of international migration raises a second issue- the impact of conationals' irredentism on ethnic minorities in the receiving countries.}

monthly. To discourage the out-migration of Russian Germans, the German government is prepared to send financial aid to build the German Autonomous Republic in the Volga region (Orlova, this issue). Similarly, the Bulgarian government has sent aid to promote Bulgarian ethnic culture in Moldova, Ukraine and Serbia (Iordanova, this issue). Even Israel has realized that it cannot continue inviting the one to five million Soviet Jews in the former Soviet Union to "repatriate." Therefore, with the help of American Jewish organizations, Israel has been providing aid to revive the Jewish culture and religion in the former Soviet Union.

In all the above-mentioned examples, nationalism has played a role in facilitating the immigration of conationals. However, nationalist sentiments can also prevent members of some minority groups, who are defined as different from the host, to return to the territories from which they were originally forced to leave.

The case in point is that of Georgia, which rejects the territorial claims of Muslim Georgians (otherwise known as Meskhetian Turks) who had been expelled from Georgia to Central Asia un-
(Iordanova, this issue). The return of thousands of Russians stirs up nationalist sentiments and jeopardizes other ethnic minorities, such as Tartars, Georgians, Armenians, Central Asians and Jews who are living in Russia.

Finally, an interesting topic for future research is the social integration of migrants who have the same ethnic background as the hosts. Social relations between the migrants and their hosts will depend in part on the extent to which the former have been able to maintain their ethnic culture and language in the country where they resided, and the extent to which these have changed in the receiving country. As in the case of Pontic Greeks, the Pontic dialect is different from modern Greek, making it difficult for the migrants from the former Soviet Union to integrate into the new society (Vergeti 1991). Alternatively, cultural andlinguisticaffinity would facilitate the integration of new arrivals. However, other circumstances may mitigate against their full integration. Studies in the field of ethnic relations (see Barth 1969, for instance) have led to conclusions that cultural and linguistic similarities are not sufficient to ensure acceptance of migrants if there are economic or political reasons for the hosts to see them as different. Thus, for instance, Soviet Jews found that they were different from the sabras (Israelborn Jews) and Jews who came to build Israelbefore them (Horowitz 1989). Similarly in Greece, Pontic Greeks from Russia found that they were perceived as Russians and not as Greeks and consequently they were socially marginalized (Vergeti 1991; Voutira 1991). Empirical research will allow us to outline those conditions in which cultural differences are ignored in order to define a migrant group as a part of "us," and those circumstances under which slight cultural differences are exaggerated so that new arrivals are seen as "them."

\section{Note}

1. Anthony Smith defines "irredentism" as those nationalist movements that aim to unify all conationals in one state. For him, the drive behind this movement comes from those who already reside in this state and who wish to strengthen it and, in many cases, expand its boundaries by adding the territory on which their separated kinsmen reside, if this territory is adjacent to theirs (Smith 1983, 222). The sense in which $I$ use this term is similar to Smith's in terms of results (with a possible exception of the annexation of new territories), but the impetus for this movement in many cases that I discuss comes more from those outside their ancestral lands than from those already living there.

\section{References}

Barth, Frederic. 1969. Ethnic Groups and Boundaries. Bergen: Universitetsforlaget.

Horowitz, Tamar, ed. 1989. Soviet Man in an Open Society. Lanham: University Press of America.

Kokkinos, Dimitris. 1991. "The Reception of Pontians from the Soviet Union in Greece." In Journal of Refugee Studies 4, no. 4:312-14.

Noelte, Earl. 1992. "Reflections on Hungary." In Refuge 12, no 4:4-6. (October).

Ryvkina, Rozalina, and Rostislav Turovskiy. 1993. The Refugee Crisis in Russia. Toronto: York Lanes Press.

Salitan, Laurie P. 1992. Politics and Nationality in Contemporary Soviet-Jewish Emigration, 196889. New York: St. Martin's Press.

Smith, Anthony. 1983. Theories of Nationalism. New York: Holmes and Meier Publishers, 1983.

Vergeti, Maria. 1991. "Pontic Greeks from Asia Minor and the Soviet Union: Problems of Integration in Modern Greece." In Journal of Refugee Studies 4, no. 4:382-94.

Voutira, Effie. 1991. "Pontic Greeks Today: Migrants or Refugees?" InJournal of Refugee Studies 4, no. 4:400-20. 